PEDAGÓGUSKÉPZÉS, 10-11 (39-40), 2012-2013. 117-132.

\title{
A GYAKORLÓTANÍTÁS EGY GYAKORLATVEZETŐ MENTORTANÁR KALEIDOSZKÓPJÁN KERESZTÜL
}

\section{Kozsánné Tóth Marianna}

\author{
a Teleki Blanka Gimnázium \\ tanára \\ ktmaya01@gmail.com
}

\section{Előzmények}

Magyar nyelv és irodalom, valamint finn nyelvtanárként 16 éve vagyok a pályán. Ha a kérdésre rövid választ keresek, azt mondhatom, nemcsak tanítani, de tanulni is szeretek. Szeretem frissnek érezni magam a szó bármely értelmezési körét tekintve. Jóleső és izgalmas érzés szellemileg frissnek maradni. Megújulási lehetőségként élem meg a továbbképzéseket. Mindet. Sosem éreztem, hogy „túlképzett vagyok". Azt sem, hogy egy tanár megállhat. A diákok sem állnak meg.

Fontos mozgatórugó volt számomra, hogy jól emlékszem az én gyakorlati időszakomra. A patinás egyetemváros. Debrecen. A minőségi felsőoktatás garanciája e név: Kossuth Lajos Tudományegyetem. Öt év tanulás után két hét szakmai gyakorlat szakonként. Két minden szempontból kompetens vezetőtanár. Megértö, gondoskodó, de erős és következetes emberek. Mindig érdekelt, mindezt hogyan is lehet összefogni. Emellett láttam azt is, hogy pár hallgatótársam e néhány óra alatt döbbent rá arra, hogy hiába az elmúlt öt év kimerítő munkája, nem fog tanítani soha... Miért is? A kulcs talán a mentorálási folyamatban van?

Számunkra ennyi volt a gyakorlat, aztán jött a minden jelenleg gyakorló pedagógus által ismert mélyvíz. Álláskeresés. Örülnek a fiatalság erejének, de legalább három év szakmai tapasztalatot várnak el. Pályakezdőként ez már akkor is lehetetlen volt. Óvodától általános iskoláig, szakközéptől gimnáziumig vezetett az út számomra. Szakmai és módszertani szempontból felkészülten, de „üvegbúra alól” lépett ki ez a generáció az oktatás világába. Az iskolák tantestületének sajátja volt a látszatra befogadó, valóságban kirekesztő magatartás is. A „mi is kiszenvedtük” szemléletmódból kevesen mozdultak ki.

Jelenlegi munkahelyemen 12 éve dolgozom. Itt találkoztam elöször olyan segítő odafordulással az intézmény tanári kara, vezetösége és a munkaközösség vezetője részéről, ami arra késztetett, hogy maradjak itt. Értéket közvetíteni emberi, szakmai, pedagógiai és pszichológiai tekintetben. Ezt a hitvallást kaptam a Teleki Blanka Gimnázium tanáraitól. 
Az EKTF gyakorlatvezető mentortanár szakvizsgával záruló képzésén 2010. őszétől, az első induló csoportban vettem részt. Vonzó volt a képzés témája, a szakmai előrelépés lehetősége, a hétvégi órák, melyeket gyakorló tanárként a munkám mellett is elvégezhettem. A TÁMOP 3.1.5 pályázata a munkahelyemmel közösen nyitott lehetőséget arra, hogy e szakirány felé léphessek. Mindezzel párhuzamosan tehetségfejlesztőként is végeztem 2012-ben.

\section{A mentorképzésről}

Az EKTF pedagógus szakvizsgára felkészítő gyakorlatvezető mentortanár szakirányú továbbképzése tudatosan rendszerezett tantárgyaival, egymásra épülö feladataival maratoni munka elé állított bennünket és tanárainkat egyaránt.

A négy félév alatt teljesítendő 360 kontakt óra, 120 kreditpont teljesítése kezdetben ijesztő mennyiségnek tủnt, de a tanegységlista áttekintése után bár maratoni, de teljesíthető feladattá szelídült. Ennek valódi oka, hogy a tanult tárgyak olyan ismereteket adtak, amelyek fokozatosan érdekes rálátást engedtek a nevelési-oktatási intézmények szervezeti kérdéseibe elméleti és gyakorlati síkon egyaránt.

Az alapozó képzés előadásai, érdeklődést felkeltő témakörei első lépésben ajtókat nyitottak a nagyvilág oktatási folyamatainak megismerése felé. Emellett a gyakorlati órák, személyiségfejlesztő tréningek a szemléletmódváltást szorgalmazták. Jól ütemezett feladataival elérték a pedagógusok, vezető tanárok módszertani tárházának bővülését. Carl Rogers személyközpontú szemléletmódjának vagy a kompetencia alapú pedagógusképzésnek megismerése szükségszerü és építő volt számunkra.

A pedagógus életpályamodell áttekintése során tisztáztuk a mentor feladatkörét, szerepét. Emellett a reflektivitás fejlesztésére, a hallgatóval eddig kialakult kommunikációs rendszer bővítésére is sor került.

A törzsképzés legfontosabb elemei véleményem szerint a gyakorlati tárgyak voltak. Ezek épültek be szük értelmezésben az elmúlt két év mentorálási folyamatába iskolánkban. Az IKT alkalmazási lehetőségei, a facilitátori feladat fő mérföldkövei, a speciális pedagógiai feladatok mind-mind a szakmai fejlődésemet szolgálták.

Mi is generálja az oktatásban végbemenő változások szükségszerüségét? Ez a képzés zárása után, a mentori munkámban való elmélyülés során már nem kérdés. A változó világ, a Z-generáció harsány lendülete magával ragadó, csak velük együtt haladva juthatunk előrébb mi is. Így minden továbbtanulási lehetőség megerősítést, új lendületet ad. Az új feladat pedig mindig örömteli kihívás, ha valami építőt lehet tenni a minőségi oktatás fenntartásáért, a szakmai és módszertani eszköztár bővítéséért, a pedagóguslét szebbé tételéért, érdemes lépni. 


\section{Mentorálás a gyakorlatban}

\section{Az egyéni gyakorlatot végző hallgatók mentorálása}

Az elmúlt két év tapasztalata alapján mondhatom, hogy az elméletben felépített folyamat müködőképesnek bizonyult a gyakorlatban. Az EKTF két hallgatót küldött hozzám az előző évben, magyar-kommunikáció és matematika-pedagógia szakon. Emellett az ELTE mentoráltja történelem, a KRE hallgatója német és történelem szaktárgyi területen gyakorolt gimnáziumunkban. A 2012-es öszi félévben a KRE egy német, egy angol és egy magyar-történelem szakos hallgatót küldött hozzánk, míg az ELTE részéről egy filozófia-magyar szakos egyetemista érkezett társával, aki család- és gyermekvédelem szakja mellett magyar nyelv és irodalomból végezte gyakorlatát nálunk. A létszámra való tekintettel kisebb mentori és szakmai munkacsoport jött létre is a hallgatók támogatására, hiszen öt hallgató nyolc szakterületen kezdte meg feladatait hat szakmai konzulens és egy mentortanár irányításával.

A szemléletmódváltás eredménye, hogy a mentorált és mentora között kialakuló bizalmi légkör nyitottá és érdeklődővé teszi a hallgatókat, módszertani színességre, kreatív problémamegoldásra egyaránt ösztönzi a szakmai konzulenseket is. Az alá-fölérendeltség megszünése eredményezi a partneri viszonyt a szó pozitív értelmében.

A 17 hét alatt elsajátított ismeretek megszerzése a hagyományos értelemben vett tanítási gyakorlatról is ismert, bár az akkori képzési idő rövidségét tekintve kevesebb sikerrel kecsegtetett. A munkahely világával való megismerkedés viszont korántsem volt természetes hozadéka az előző oktatási folyamatnak, inkább csak szakmai gyakorlatnak tekinthettük, mintsem tanári kompetenciát fejlesztő folyamatnak.

Jelenleg viszont célul tüztük ki nemcsak a gyakorlati ismeretek megszerzését, de a munkahely világával való ismerkedést is. A mentor és mentorált közös feladata volt, hogy szerezzenek jártasságot a tanítási és tanulási folyamatok értékelésében, fejlesztésében, az iskolaszintủ kutatások, mérések értékelésében egyaránt.

Ezen területek részletesen a tanári kulcskompetenciákhoz kapcsolhatók, azaz a már ismert 9 tanári kulcskompetencia kialakítása és fejlesztése lett a cél.

A gyakorlat elején a mentoráltak jelölik ki maguk számára a fejlesztendő kompetenciaterületeket. Kiscsoportos megbeszélésen mutatják be a választott szempontokat annak tükrében, hogy erősségüket és gyengeségüket miben látják. Az elhangzó gondolatokat írásban rögzítik, a fejlesztési ívet így egyénileg jelölik ki maguk és mentoruk számára egyaránt.

Az eddigi tapasztalatok azt mutatják, hogy alábbi területek megjelölése kiemelkedik a többi közül: a tanulói személyiség fejlesztése a tanulói csoportok, közösségek alakulásának segítése, a pedagógiai folyamat tervezésére, a tanulók müveltségének, képességeinek fejlesztése. Néhány hét ismerkedés után bővül a már ismertetett terület a tanulási folyamat szervezésével és irányításával; a pedagógiai 
értékelés változatos eszközeinek az alkalmazásával, a szakmai együttműködés és kommunikáció fejlesztésével. Végső célként jelent meg a mentoráltak reflexióiban a szakmai fejlődésben elkötelezettségre és önmüvelésre.

Érdekes volt számomra, hogy kezdő tanárként a szempontok fordítva kerültek elő: először azt ellenőrizték, miként teljesítek szakmai szempontból az óráimon. Ez a folyamat nagyon előnyösen megfordul, beilleszkedni egy közösségbe első lépésként fontosabb lehet.

\section{Résztvevök}

A mentorálási folyamatnak részese volt minden esetben a mentorált, mellette a felsőoktatási intézmény részéről egy koordinátor, mellette a gyakorlatkísérő szemináriumon a gyakorlatvezető tanár heti egy alkalommal, ha nem egyezett a szakommal a mentorált szakterülete, akkor szakmai konzulens segítségét kértem, a mentori tevékenységet minden esetben én láttam el, de természetesen szükséges az egész intézmény befogadó, támogató, együttműködése is.

E kapcsolati háló mindkét évben remekül müködött, zökkenőmentes közös munka jellemezte a tanéveket. Egy újabb cikk témája lehetne, miként könnyíthetnénk a kapcsolattartáson, a financiális ügyek intézésén, de ezen cikk keretei ezt nem teszik lehetővé.

\section{A pályakezdő gyakornokok mentorálása}

Azt mondanám, a gyakornokok mentorálása közös értékkeresés, személyes nevelés, a pályakezdő tanárokat támogató folyamat, ahol a kapcsolati dinamikában mindkét fél elörelendül.

A mentortanár ebben az értelemben a pályakezdő tanárok szakmai szocializációját támogató kolléga, szorgalmazza a beilleszkedést és a pályán maradást. Számos feladata közül szerintem e két jellemző kiemelten fontos, hiszen ki tanít majd, ha nem tesszük vonzóvá a pedagógus pályát? Így válhat külön a szakmai konzulens és a mentor tevékenységi köre adott esetben. A fenti kérdésre ez adhat választ. A szakmai konzulens, a vezető tanár hagyományos értelemben szakmai előmenetelben gondolkodott. Itt inkább Vekerdy nyomán a „született pedagógusság” felismerése, felismertetése és fejlesztése a cél.

A mentor tehát facilitátor. A tudás átadásának és akarásának képességével bír, az élethosszig tartó tanulás jegyében végzi munkáját. Helyzettől függően jó barát, gyámolító, pártfogó, jellemzi a szociális érzékenység. Hagyományos értelemben vett vezetőtanár is, aki komoly szakmai múltra tekint vissza, legalább 10 éve van a pályán. Magas szintü, biztonságos szakmai tudás birtokosa, emellett módszertani gazdagság és igényesség jellemzi óráit. Folyamatosan törekszik az önfejlesztésre is. 


\section{Az egyéni összefüggő gyakorlat mentorálása}

A mentorálási folyamat három területen érintheti a gyakorlatvezető mentortanárt.

a) Első és talán legszerencsésebb megoldás, ha a mentor és mentorált ugyanazon szakterületen dolgozik mindkét szak tekintetében. Ekkor ő látja el a szakmai-konzulensi feladatokat és a mentori tevékenységeket egyaránt.

b) Volt olyan eset is, mikor csak a magyar szak mutatott egyezést. Ekkor történelemből szakmai konzulenst kértem fel iskolánkban, így a 30 órára terjedő tanítási feladatokat a történész kolléga óráin töltötte a hallgató, minden kísérő szakmai konzultáció kettőjük feladata volt, a mentorálást én végeztem.

c) Ebben az évben két esetben előzőleg egy esetben volt olyan hallgató, akiknek egyik szakja sem egyezett a saját szakommal, matematika, német vagy angol tanári gyakorlatukat töltötték nálunk. Ekkor a szakos szakmai konzulensek látták el a fentihez hasonlóan a szakmai feladatokat, a mentorálás egyéb feladatai maradtak továbbra is nálam.

A munkafolyamatot a könnyebb áttekinthetöség érdekében három munkafázisra bontottam. Minden munkafázist megelözött és követett egy megbeszélés, a hallgatók írásban is leadták a reflexióikat a kitüzött célok, feladatok teljesítését illetően.

Az elsö szakasz a tanév megkezdésétöl az öszi szünetig tartott. Mielött megérkeztek a mentoráltak, tartottam egy részletes tájékoztató megbeszélést a leendő szakmai konzulensekkel a feladatokról. Részletesen áttekintettük a továbbképzésen tanultakat, mit is jelent a facilitátori szerep, hiszen a mi munkánknak feltétlenül koherensnek kell lennie mindvégig, akkor lehetünk hiteles személyek a hallgatók mellett. A munkaforma újszerü volt számukra, de a beszélgetés végén egyértelmüvé vált, mi az ö szerepük, mi az én feladatköröm. Aztán megteremtettük véleményem szerint a legmegfelelőbb munkakörülményeket: az elöző évben is, mind a négy hallgató, most mind az öt hallgató kapott saját asztalt, széket, kulcsokat az én irodámhoz, így a hirtelen adódó problémák megoldására is azonnal sort tudtunk keríteni. A bevezetés az iskola életébe augusztus végén vette kezdetét: a nyitó értekezleten bemutattam a kollégáknak a hallgatókat. Fontosnak tartottam egyértelmüvé tenni, hogy ők nem kistanárok, nem gyakornokok, hiszen mi már ezzel a végzettséggel munkába álltunk pár éve. A tanulmányaik záróakkordja a gyakorlat ezen formája, így arra kérem őket, tekintsenek pályakezdő kollégaként rájuk.

A hallgatók visszajelzése pozitív volt minderről, sokat jelentett nekik, hogy partnerként mutattam be őket, segített a kezdeti félelmek legyőzésében az, hogy mondhattak magukról néhány szót. Otthonos körülmények várták őket az irodában is, így nyugodt körülmények közt határozhattuk meg további feladatainkat. Akinek volt kedve, részt vehetett már a gólyatáborban is, tapasztalatait írásban adták le nekem. 
Az év kezdetén tisztáztuk a csengetési rendet, a legfontosabb elvárásokat a pontosság és a felelősség terén. Az órarendi lebontás után igyekeztünk figyelembe venni az egyéni kéréseket, a célkitüzések megalkotása után jelöltük ki, kinek melyik osztály segíthet leginkább az előrelépésben. A célkitüzések, kompetenciaterületek írásos feladatot is jelentettek számukra.

Megismertettem őket az iskola felépítésével, a tanulói létszámmal, iskolánk profiljával. Megnéztük az épületet, a termek elhelyezkedését, az IKT-s lehetőségeket. Ismerkedtünk az iskola történetével, a pedagógiai program és házirend megismerése otthoni feladat volt. Idén tennivaló is akadt bőven, a program megújításán a hallgatókkal együtt dolgoztunk. A munkaközösségi értekezleten éppúgy részt vettek, mint a kirándulásokon. A teljesértékủ kolléga pozíció előnyeit és hátrányait is megismerték, egyre nehezedő feladatokat kaptak tőlem. Minden olyan folyamatról vártam és kaptam reflexiókat, amiben részt vettek.

Gyakran csoportos megbeszéléseken vettünk részt, ahol áttekintettük a teendőinket. Az órarendbe beterveztük előre, mely hallgatóval mikor tudok négyszemközt egyeztetni, és mikor tartunk komplex megbeszélést, ahová mindenki elhozhatja kérdéseit, amivel társait is segítheti. (Ennek valódi jelentősége akkortól volt, mikortól már órát is tartottak a hallgatók.) Ebben a szakaszban tisztáztuk, hogy részletes óratervezeteket fogok kérni mindaddig, míg szükségét látom. Ennek formaisága egyértelmü volt mindenki számára.

Első osztálytermi feladat volt a jelenlét a szakórákon, kiemelten azokon, ahol majd ö fog tanítani, de más órákon is hospitáltak. Nagy figyelmet fordítottam arra, hogy ne szaktárgyi szempontokat adjak, hiszen mindezzel a rövid gyakorlaton már sokat foglalkoztak. Visszajelzésük alapján fontos volt a személyes példaadás, közelebb kerültek a tanításhoz, szembesültek a mindennapos tanítás örömeivel és nehézségeivel rajtam keresztül is.

Változó ütemben kezdték a tanítást az osztályokban. Volt, aki már két hét után tanított, ekkor volt módszertanilag indokolt a munkafolyamatba kapcsolódás, de volt olyan is, aki az első három hétben csak hospitált. Mint a diákoknál is, itt is élni kell és lehet véleményem szerint az egyéni differenciálás lehetőségével. A szakmai tanácsadói szerep hangsúlyossá vált a tervezetek áttekintésében. A megtartandó órák ötleteit szóbeli beszélgetés, ötletbörze formájában dolgoztuk fel egy héttel korábban. Minden héten szombat estig vártam a tervezeteket, majd egy nap múlva viszszaküldtem reflexióimat. Ez nagy munka volt mindenkinek, de megérte a befektetett erőt, mert magabiztosabban mentek szakórákat tartani a hallgatók.

Az őszi szünet jó lehetőséget biztosított számukra, hogy rendezzék a portfólióba szánt dokumentumaikat, reflexiókat írjanak az első szakaszban kijelölt célokról és megvalósulásukról. Néhány hét után már teljesen természetesen mozogtak iskolánkban és az osztályokban egyaránt. Felmérték a diákok munkatempóját, bár így is gyakorta „túltervezték” az órát, amit sose éreztem problémának. 
Emellett a tanmenetek elkészítése saját módszertani ötleteikkel vált gazdagabbá, a rengeteg munka ellenére mégis pozitív visszajelzést kaptam, örömmel dolgoztak kollégáimmal együtt, előrelátóan gondoltak jövőjükre.

Néhány gondolat az első szakaszról a mentoráltak szemszögéből a mentoráltak terveiröl, céljairól, észrevételeik az elsö fázisban:

- „Célom az új tapasztalatok összevetése az eddig megtartott 15 óra élményeivel."

- „Miből élek meg a gyakorlati félév alatt?”

- „Szeretném megtalálni azt az örömöt, amit az elkötelezett tanárok éreznek, amit mentorom óráin látok."

- „Célom: gyakorolni a helyes időbeosztást, minimálisra csökkenteni a dokumentációval töltött időt."

- „Megerősödött önbizalommal, és növekvő tudással (szaktárgyi, pedagógiai, módszertani), határozottan tudjak belépni a diákok közé.”

- „Hasznosnak éreztem a kirándulásra kísérni a gyerekeket, alaposabban megismerhetem öket e néhány nap alatt, felelősséggel tartoztam irántuk.”

A második szakasz a szünet végétöl kezdödött, november végéig tartott. Elöször a reflexiókban felmerülő kérdéseket beszéltük meg közösen is, egyénileg is. A további munkánkra vonatkozó javaslatokat átgondoltam, beépítettem a későbbiekben a feladataink közé, amennyiben szükségét éreztem.

Egyik központi kérdés számukra az volt, milyen munkát tudnak vállalni a félévi gyakorlat alatt, hiszen a felkészülés, bent tartózkodás teljes embert kíván, még ha csak 2-8 órát tartanak is egy héten. Felmerült az ösztöndíj igénylése, esetleg étkezési utalvány, utazási költség támogatása, hogy abban a félévben is meg tudjon élni a hallgató valamiből. Az én problémám pedig az időhiány volt.

Új célokat tüztünk ki magunk elé, a ránk váró feladatok tükrében határoztak meg egyenként a fejlesztendö kompetenciaterületek közül kettőt. Most már mindenki tanított a saját csoportjában, osztályában. Elfogadható volt ekkor már a tervezet helyett a rövidebb óravázlat is, mely csak az időt, témát és alkalmazott munkamódszert jelölte. A vázlat bemutatásának időpontja nem változott. A szakmai konzulens illetve mentortanár az órák zömén részt vett. Minden órát megbeszélés követte. Nem hiszek a tömbösített megbeszélésben, bár ezt a javaslatot kaptam, mikor az időhiányra utaltam. A hallgatónak semmiképpen nem jó, ha a feszültséget viszi magával egész héten, esetleg a következő órára is.

Problémát jelentett viszont, hogy ahol szakmai konzulens dolgozott, gyakori óraütközések miatt csak néha tudtam részt venni a hallgató óráján, pedig ennek gyakran szükségét érezte volna mindenki. (Sokat segített viszont a videofelvétel, ami az órákon készült. A videotrénerség lehetősége remekül kiegészítheti e tevékenységi kört a későbbiekben.) Ezt a problémát természetesen feloldja majd eset- 
leg, ha ö is elvégzi a mentorképzést. Vitathatatlanul dinamikusabb és koherensebb lehetne a fejlesztés így.

Ebben a munkafázisban hangsúlyossá váltak az egyéb tevékenységek is, hiszen az óravezetés lassan szerves része lett a mindennapoknak. A szakköri foglalkozások, felzárkóztató órák mellett a színházlátogatások szervezése, kirándulások kerültek a fókuszba. Emellett az értekezleteken való megjelenés, véleménynyilvánítás lehetősége szintén a hallgatóké volt. Az iskola vezetősége felől érkező bizalomként élték meg, ha néha-néha bemehettek helyettesíteni. A szerteágazó terhelés, olykor aránytalan munkaeloszlás, ami egy pedagógus számára természetes, a pályakezdő számára hihetetlen erőbefektetést igényel, azt tapasztaltam. Lendületesen vettek részt iskolabörzék szervezésében, lebonyolításában és a háttérmunkákban egyaránt velem együtt.

Egyre oldottabban dolgoztak, legtöbbször ebben a szakaszban került sor a bemutató óra megtartására. Fontos tudni, hogy ez nem egyenlö a vizsgatanítással, ebben a folyamatban nincs zárótanítás, nincs „kirakatóra”. Az egyetemek és az iskolák igazgatói betekintést nyerhetnek a fejlesztési folyamatba, megfigyelhetik azt. A hallgató a megbeszélésen tájékoztatja a kollégákat, hol is tart, mivel elégedett, mivel nem annyira. Mely területen szeretne változtatni, fejlődni. Mennyire ismerte meg a csoportot, hogyan sikerült megvalósítani az óra célkitüzését, hogyan érezte magát a munkafolyamatban.

Ezután a mentortanár tájékoztatja a kollégákat a megjelölt kompetenciaterületeken mutatott fejlődésről, aktuális helyzetről. A Gordon-tréningen elsajátított kérdéskultúrával vezeti rá a hallgatót a felmerülő kérdések önálló megoldására, ezzel támogatva az interiorizációt. Ezt követően tesz javaslatokat, mond ötleteket az egyetemi szakmai konzulens, az iskolai konzulens, (ha volt ilyen), végül az iskola vezetője segítő hozzászólásával viszi előrébb a mentorált munkáját úgy, hogy előremutató megjegyzései ösztönözzék a hallgatót a további fejlődésre.

Nézzük a mentoráltak gondolatait. Tervek, célok, igények a második munkafázis kezdetén:

- „örülök, mert új célokat tüzhetek ki magam elé”

- „az eddig észrevett hibáimat szeretném korrigálni”

- „szeretnék minél több külső programot szervezni a diákokkal, mert jó volt az iskolabörze, kirándulás is"

- „a csendes gyerekekre is tudtam figyelni”

- „végre csökkent a dokumentáció, alakul a portfólióm is"

- „nehéznek érzem az osztályfőnöki munkát”

- " "Szeretnék kreatívabb lenni a többiek óráját látva.”

- „Lassan elfogadják jelenlétemet a kollégák, bár még mindig kérdés a tegezés - magázás."

- „Már jól ismerem az iskola dokumentumait." 
A harmadik fázis már nem jár új feladatokkal, bővítéssel, a változás inkább a tevékenységbe való elmélyülésben határozható meg elsőként. A fenti reflexiók, a szakmai konzulensek, mentoráltak és a mentor közös megállapodása alapján egyre kevesebb: az egyéb tevékenységekhez füződő reflexiók dokumentálása, kirándulásokról készített összefoglalók a fejlődési ív tükrében, az óratervezeteket is felváltják a vázlatok, viszont kialakul az igény az önálló órák tartására. Ekkor már, tervezetten legalább a megtartandó órák 20\%-ban, azaz legalább az utolsó két-három munkahétben, sikeres tevékenység esetén akár négy-öt héten keresztül, már a téli szünet előtt is egyedül taníthatnak a mentoráltak. Természetesen ez is egyedi elbírálás alá esik, de úgy gondolom, hogy a mentor és metorált között 12 hét alatt kiépülő bizalmi viszony, a mentor szakmai meglátása, valamint a munkafolyamat sikerességének mérőeszköze az, hogy beengedem egyedül az osztályterembe, megbízom benne.

Eddigi tapasztalatom az, hogy a saját osztályban való hosszas munka eredménye, hogy egyre bátrabban használnak új módszereket a hallgatók, hiszen ismerik a közösség igényeit. Kialakul egyéni hangjuk, a diákok elfogadják őket. Kialakul az a védett burok, amiben a diákok és a mentorált vannak benne, és én kerülök megfigyelö pozícióba.

Az első órák egyikéről készült videofelvételek mellett új felvételek készülnek olyankor, mikor hátul ülök, bent vagyok, és akkor is, mikor nem vagyok bent, melyeket szupervíziós megbeszélés követ. (Ha közösség vagy a mentorált kéri, nem készül felvétel az órákról, de eddig csak egy hallgató jelezte ezt, a többiek jól felismerték az ebben rejlő fejlődési lehetőségeket.) Nagy öröm volt mindenkinek, hogy tanárként láthatta magát és azt, hogy tanárként fogadták el öket a diákok. Összetartoztak, fél szavakból is értették egymást, kialakult a közös kódrendszer verbális és nonverbális eszköztára. A cél ez volt, hogy igyekezzünk az érintett közösségben a kapcsolati hálót feltérképezni, reflexiót írni mindezekről, a portfólió feladatainak megfelelően. (Ebben az egyetemek részben eltérö követelményrendszerrel dolgoztak.)

A harmadik szakasz zárásakor már távlati tervekről beszélnek általában a hallgatók, minősítik a közös munkafolyamatot, az iskola együttmüködését, a diákokkal való kapcsolatukat. Minden esetben úgy köszöntek el a tanítástól, saját csoportjuktól, osztályuktól, tőlem, hogy hiányozni fog közös munka, a gyerekek, a kollégák. Legnagyobb elismerés számomra, hogy mindannyian a tanári állásban gondolkodnak, már keresik a lehetőséget, örömüket lelték a képzésben, a tanításban, elkötelezettjei lettek a pedagógusi pályának. Így mozdul előre végül minden esetben az utolsó kompetenciaterület is az egész életen át tartó tanulás ügyének szolgálata felé, a tanítás és tanulás irányába. E kettő helyes arányának megtalálása adhatja a tanárság valódi örömét hosszútávon. 
Nézzük, miként is látják visszatekintve a hosszú gyakorlatot, a mentor tevékenységét, saját munkájukat a hallgatók.

Értékek:

- „Jónak és fontosnak találtam a mentor-mentorált szakmai kapcsolatát, támogató, elfogadó légkörben bátran kérdezhettem tőle."

- „A mentor törekedett arra, hogy én magam jöjjek rá a megoldásra a beszélgetések folyamán, és ebböl sokat tanultam."

- „Hatalmas segítség volt szakmai szempontból is a mentorom, rengeteg könyvet ajánlott, melyek segítették felkészülésemet."

- „Teljesen más viszony alakult ki köztem és csoportjaim közt, mint az eddigi gyakorlatok alatt."

- „Konfliktuskezelési stratégiám sokat fejlődött. Bár tudtam, erős támasz van mögöttem, de meg kell tanulnom kiállni önmagamért."

- „A gyakorlat óriási előnyének tartom, hogy kipróbálhattam az egyetemen tanult változatos módszereket, aktívan részt vehettem az iskola életében."

- „Nagy volt a felelősség a vállamon, de fantasztikus volt a siker megélése is."

A felmerülö nehézségek:

- „Legnagyobb negatívum az őrületes mennyiségű adminisztráció az egyetem felé (68 oldalas heti igazoló). Elveszi az időt a valóban lényeges feladatoktól." (Megjegyzés: ez idén már körülbelül 20 oldalra csökkent.)

- „A mentorált nem 'kistanár', mégis éreztem a kezdetekkor a bizalmatlanságot a kollégák felől, bizonyítanom kellett..."

- „Jó ötlet a féléves szakmai gyakorlat, de szerintem január végén kellene zárulnia az osztályozó értekezlettel, hogy a folyamatot végigkísérhessük mi is."

- A nagy osztálylétszám (37 fö) hátráltató.”

- „Most már csak az a kérdés: sikerül-e tanárként elhelyezkednem valahol?"

\section{Jelenből a jövő felé}

Mit lehetne tenni a színvonalas elörelépés érdekében? Kitekinteni a gyakorlatban megvalósuló mentorálási folyamatra, hiszen vagyunk már páran az országban, akik végzett gyakorlatvezető mentortanárként dolgozunk. Visszajelzéseink sokrétüek lehetnek. A folyamatban részt vevők reflexióit összegyüjtve, alapos kutatómunka után érdekes lenne egy tanulmányban összegezni a felsőoktatási intézmények gyakorlatvezető tanárai, a hallgatók és a fogadó intézmények, a iskolában tanuló diákok és a mentortanár és a szakmai konzulensek tapasztalatait összevetni. Mindez érdemi támpontot adhat a továbbképzésekhez, a fejlesztési folyamatban szükséges módosításokhoz egyaránt.

Másrészt érdemes lenne a hallgatókat a gyakorlati félévet megelőzően tájékoztatni a lehetőségekhez mérten - akár a partner iskolában dolgozó mentortanár se- 
gítségét kérve -, milyen feladatok is várnak majd rá a gyakorlat során. A két év alatt összesen kilenc hallgató általában két szaktárgyi területen végezte nálunk gyakorlatát. Sokat jelentett volna a munkafolyamat kezdetén, ha már úgy érkezhetnek hozzánk, hogy tudják, mely évfolyamban fognak dolgozni, milyen osztálylétszámban kell gondolkodniuk, milyen tankönyvcsaládból dolgozik az adott osztály. Egy látogatás a várható partneriskolában szintén oldaná az ismeretlennel szembeni feszültséget. Augusztus végén szembesülni mindezzel, miközben már megismerkedhetne a könyvekkel a nyár folyamán is, készülhetne a tananyagokkal elöre, hogy ne a dokumentáció vegye el a munkára fordítható idő nagy részét.

Tapasztalataim szerint a hallgatók természetesen ,jártak be" dolgozni, néhány hét után megszokták az iskola sajátos ütemezését, bár beszámolójuk alapján mindez igen fárasztó volt.

A tanítási folyamatok sokszínüségének megismerése mellett betekinthettek az értékelési rendszerbe éppúgy, mint az egyéni fejlesztési lehetőségekbe. E folyamat már egyénített volt számukra is, attól függően, ki melyik csoportban ténykedett. Az egyéni fejlesztés mellett a hallgatók eredményességét növelte a kiscsoportos megbeszélések sora, ahol felvázolhatták problémáikat, közösen kereshettek megoldást mindezekre.

Valódi örömforrás volt a mentorált, szülö, diák és a mentor számára is, hogy aktívan részt vehettek a fogadóórán. A rájuk bízott csoport ügyeit, a felmerülö konfliktusokat egy előzetes megállapodás alapján úgy építettük fel, hogy a szülö bemutatkozása után mindketten bemutatkoztunk. Ezt követően ismertettem a mentorált szerepét, helyzetét a nálunk zajló oktatási, nevelési, képzési folyamatban. Az ezt követő kérdés a szülöhöz irányult, elfogadja-e, hogy a beszélgetésben mindhárman részt vegyünk? A szülők rugalmasak és érdeklődőek voltak, mindenki kíváncsi volt a mentorált és mentor véleményére egyaránt. Kifejezetten elörelendítette a hallgatókkal a munkafolyamatunkat, hogy a szülök hozzájuk fordultak kérdéseikkel, hiszen az adott csoporttal ekkor már hetek óta dolgoztak együtt. Remek érzés volt, hogy senki nem kérdőjelezi meg tanári kompetenciájukat, hiteles forrásnak bizonyulnak a felmerülő nehézségek kezelésében pedagógiai, pszichológiai és szaktárgyi tekintetben is. Természetesen jelen voltam a beszélgetéseknél, szükség esetén kisegítettem pályakezdő kollégámat. A tanárság egy másik oldala, a felelősség érzete erősödött ezáltal bennük leginkább reflexióik alapján. Ennek fontosságát én is hangsúlyoznám.

A mi esetünkben nem a tekintélyelv, mintsem a facilitátori szerep volt hangsúlyos mindvégig. A facilitátor tehát az, aki egyszerre ad keretet és teret a kitüzött célok eléréséhez vezető folyamatoknak, „kívülről katalizálja a folyamatokat anélkül, hogy tartalmi kérdésekben állást foglalna" (Barcy, 52. o.).

Ennek megvalósulására mindvégig tudatosan figyeltem én is, a mentoráltaktól is ennek sikerességéről kaptam visszajelzést a záró reflexiókban. Így a megvalósítás folyamatára koncentrálva próbáltam segíteni a mentoráltat célja elérésében. Igyekeztem odafigyelni, hogy minden résztvevő kifejthesse véleményét, oldott légkör- 
ben, hetente egy alkalommal kiscsoportos, valamint minden megtartott óra után egyéni megbeszélésre teremtettem lehetőséget. A folyamat végén már egyedül dolgoztak a tantermekben a hallgatók. Ennek nagy szerepe van, úgy érzem. Az osztályteremben a tanár és a diákok egy védett, csak számukra ismert „,buborékban” vannak, közös jelrendszer, nyelvi és nem csak nyelvi kód jellemzi az ekkor már a tanárral együtt mozgó csoportot. Kezdetben furcsa, majd végül jóleső érzés töltött el, amikor azt éreztem, már én vagyok a „buborékon” kívül, hátul ülő „,vendégként”. Ennek elfogadása mutatja a hallgatók képzésében a szemléletmódváltás valódi lényegét. Ettől a ponttól az osztály vagy csoport már az „ő osztálya”, a felelősség, de az öröm is elsősorban az övé a szakórákon. Ennek súlya néha ólomként nehezedett rájuk, néha ajándékként, azaz megérezték, mi is a valódi tanár-szerep lényege. A csoportos megbeszéléseken ekkor a szaktárgyi kérdésekröl a hangsúly áthelyezödött az emberi értékekre. Amikor e kettő szervesen összetartozik, akkor láttam értelmét beszélgetni a tanárság lényegi gondolatairól. Kit mi motivál arra, hogy tanár legyen?

Nagy örömömre szolgált az is, hogy ekkor már egyértelmüvé vált, hogy elvarázsolta őket a tanítás, meglátták a mindennapok ajándékát egy tekintetben, egy apró előrelépésben egyaránt. Az oldott légkör, amit önnön személyiségüknek köszönhettek mindannyian másként valósult meg, de a diákok elköszönő gondolataiból az derült ki, hogy örömmel üdvözölnék őket a gyakorló tanárok közt minél hamarabb.

Gyakori lehetőség volt a módszertani ötletbörze, ahol mindenki elmondhatta megvalósítandó ötleteit. Módszertani támogatást ilyen keretek közt én is örömmel adtam, hiszen ez segíti a cél elérését. Én is megélhettem a közös munka örömét, én is tanulhattam tölük, a csoportos megbeszélések mindenki fejlödését szolgálták. Ez a mentoráltak számára is példaértékü lehet az élethosszig tartó tanulás kompetenciájának fejlesztéséhez.

E folyamat természetességére hangolódik iskolánk jelenleg, amikor a hospitálások, szakmai konzultációk bővülnek a módszertani színesítés lehetőségével.

A tanári kar barátságos, mosolygós légkörrel köszöntötte a hallgatókat, segítőkészségéről tett tanúbizonyságot az előző két évben. Nem volt olyan eset, hogy a hallgatók kéréseit ne megoldást kereső válaszreakció követte volna. Befogadó közösségünk problémaérzékenysége, toleranciája példaértékü jelenleg is. Nyitottak az új lehetöségek felé, több kolléga is jelezte, hogy örömmel látna el szakmai konzulensi, később pedig mentori feladatokat gimnáziumunkban. Ez az odafordulás eredményezte, hogy egy-két héten belül valóban otthonosan mozogtak iskolánkban a hallgatók.

Reményeim szerint közelebb viszi a mentori tevékenységhez kollégáimat az is, hogy láthattuk, a minőségbiztosítás hagyományos értelemben vett ellenőrzési rendszere a néhány órás betekintéssel nem müködhet olyan hatásmechanizmussal, mint a mentorálási folyamat, a célok sem voltak egészen azonosak. E szakmai tevékeny- 
ség megerősítésében, a folyamat kibővítésében intézményünk egy módszertani munkacsoportban látja a megoldást a közeljövőben.

Iskolánk vezetősége is gyakran részt vett a bemutató órákon, azok megbeszélésén egyaránt. Ez úgy gondolom, fontos kapcsolódási pont iskolánk, az egyetemi kollégák, hallgatók, mentorok munkájában, hiszen ekkor nyílik lehetőség arra, hogy megláthassuk, hol is tartunk, miként is haladunk, mire is kell figyelnünk közösen a későbbiekben.

\section{Záró gondolatok}

Az elmúlt két év tevékenységére visszatekintve úgy gondolom, hogy a pedagógus-szerep valódi meghatározásához és pozicionális helyreállításához elengedhetetlen a minőségi pedagógus-képzés új alapokra helyezése, melynek szerves része a mentorálási folyamat 17 hete.

A tapasztalatok alapján a mentor feladata nem az azonnali minősítő értékelés. Jelen kell lenni a szárnypróbálgatásoknál, nem repülni helyettük, mert akkor a siker nem az övék, a módszerben sem lelik saját hangjukat. Szárnyukat szegni nem pedagógushoz méltó cselekedet, a gyerekekkel sem tesszük ezt. Egyébként is tudjuk mindannyian, hogy ami az egyik közösségben müködik, az a másikban olaj a tüzre. Ha pedig nincs egyedüli, üdvözítő módszer, akkor nem szabad a meglévő ötleteket visszafogni, de ott kell lenni, ha valami nem úgy sikerül, segíteni feloldani a hibákat és következményeit, rávezetni arra, hogy maga ismerje fel az óra sarkalatos pontjait. Így, tapasztalati úton rögzül és interiorizálódik, mit érdemes tenni az adott csoportban, osztályban, az adott feltételek mellett. Ez természetesen időigényes és olykor erőt próbáló feladat, de érdemes a végső eredmények fényében kivárni a saját lépéseket, önálló gondolatokat.

Minden tanár külön egyéniség, így minden mentoráltnak is más út vezet a sikeres tanításhoz. Nem várható el, hogy az énáltalam bejárt úton haladjon, sőt! Éppen ezért örömteli és üdvözlendő minden pályakezdő tanár törekvése az egyéni utak megismerésére. Ennek fényében jól látható, miért nem cél egy „kirakatóra” megtartása a bemutató órán, miért nem a bemutató óra a folyamat záró akkordja. Ha így volna, a folyamat alárendelődne ennek a célnak, minden más csak ennek érdekében történne, teljesítéskényszerrel, vizsgahelyzettel állítanánk szembe a hallgatót. Minden hallgató más szintről indul a végső célhoz mérten, így törvényszerúen máshol áll a bemutató óra megtartásakor. Ha vizsgaóra lenne, a folyamat zárását sugallva a mentorált számára azt jelenthetné: „Kész, tanár lettem, tudok tanítani.”

Számomra a mentorálási folyamat lényege pedig ennek ellenkezője. Mindig nyitottnak kell lenni e pályán, hogy választani tudjunk eddig használt és ez után használatos módszereink közt, változni, fejlődni tudjunk szakmai és módszertani tekintetben, hogy megtarthassuk az értékközvetítés állandóságát a jövő diákjainak. Erre ösztönöztem hallgatóimat is minden esetben. 
Öröm volt megtapasztalni, hogy a hallgatók erős módszertani alapokkal érkeznek, így inkább partneri, szakmai konzultációval kezdődik a folyamat.

Módszertani frissességük szerencsésen találkozik és lendületet visz a megszokott oktatási folyamatba, míg az egyetemen a szakmai konzulensek, a helyszínen a mentortanárok támpontot adhatnak gyakorlati tapasztalataik alapján, mely csoportban milyen munkaforma javasolt.

Véleményem szerint szükségszerü felismerni helyünket a felsőoktatási intézmények, a középfokú oktatási intézmények átjárhatóságát tekintve. Amikor elindul a fejlesztési folyamat, a szakmai konzulens, mentorált és mentora, az egyetemi gyakorlatvezető tanár közt, mindenki megtalálja helyét, a kirakó képe rendezetten összeáll.

Természetesen nincs könnyü dolga egyik szereplőnek sem. Ráébredni, hogy a világ gyorsan rohan valami felé, a diákok vele, maguk mögé utasítva mindent és mindenkit. A fiatalok rohannak, versenyt futnak az idővel a jövőjükért. Mindent akarnak tudni, mindent és azonnal. A ,digitális bennszülöttnek” e tekintetben minden, míg a mentorált és mentora is tudatosan próbál e folyamatba beavatkozni, bekapcsolódni.

Fontos a megfelelö tanáregyéniség, viszont azt is látom, hogy ez fejleszthető. Az új módszerek segítségével könnyü megszólítani őket, ha mi, a gyakorló tanárok rugalmasabbak vagyunk, alkalmazkodunk a körülményekhez a tanórákon is. Ennek felismerését, a probléma kezelési metódusait kapja a hallgató többek között a gyakorlat során. Célunk, hogy a szakmaiság mellett egyéb kompetencia-területek fejlesztésére is tudjunk figyelni. Előremutató tendencia az előző évekhez képest, hogy a hallgatók magabiztosabban hozzák az elméletet a gyakorlatba. A partneriskola és egyetem közös célja, hogy a hallgató fejlödési íve követhető, rendezett és eredményes legyen. E cél másik része, hogy úgy „növekedjék”, hogy végül a munka világába való lépésekor a pedagógus pályát válassza.

Nekünk, a már pályán lévőknek az erejét is megsokszorozhatja, ha szakmai előrelépésünket nemcsak az egyéni fejlődésben, hanem a dinamikusan fejlődő oktatási módszerek megismerésében is felfedezzük. Érték a flexibilitás, a változásra való képesség is, mint minden más területen. Ezen módszerek gyakorlati alkalmazására ösztönzöm a hallgatókat, hogy szelektálhassanak, megtalálhassák végül egyéni hangjukat. Azaz maguk se vesszenek el a „kaleidoszkóp fogságában”.

Gimnáziumunk tanulóinak életkori adottsága kedvez a gyors, hatékony kapcsolatépítésnek, de olykor váratlan nehézségek elé is állíthatja ugyanez a mentoráltat. A fejlesztési folyamat végén viszont a diákok nagy szeretettel köszöntek el minden alkalommal, ami azt mutatta, hogy olyan kapcsolat alakult ki köztük, ami pozitív értelemben egy életre meghatározza a hallgató pedagógusi attitüdjét. Ez az érzékenyítés - a tanítás mögötti, feletti, melletti pszichológiai és pedagógiai folyamatok támogató segítése - adja a mentorálási folyamat újszerüségét a felkészítés ideje alatt. (Ennek részletes kifejtése egy újabb tanulmány tárgya lehetne.) 
A mentorálási folyamat tehát a fentiek fényében jól rendszerezett, logikusan felépített, tudatos és szükséges, szép eredményekkel záruló tevékenység volt iskolánkban. Néhány kérdést azonban nem hagyhatok érintetlenül.

Visszatérő nehézség, hogy a heti negyvenórás munkaidő 55-60 órára növekszik. A 22 tanóra mellé jön még 10-12 óra konzultáció (komplex megbeszélés, óratervezetek megbeszélése, pedagógiai, pszichológiai, szociológiai kérdések, videofelvételek közös értelmezése, reflexiók megbeszélése minden mentorálttal). Emellett 5-8 óra szakórai látogatás, azaz heti 55-60 óra az összmunkaidőm, ha mindenhol eleget akarok tenni.

A tanügyigazgatási szakértők szerint a törvényi háttér egyelöre nem biztosít sem órakedvezményt, sem félállásnyi lehetőséget a mentoroknak, mint a gyakorló intézményekben a vezetőtanároknak, pedig itt is félállásnyi többletmunkát jelentenek a hallgatók. Jogszabályi háttér nem áll a folyamat mögött, a jelenlegi köznevelési törvényben a feladatkör létezik, órakedvezmény a külön díjazás miatt viszont nem jár rá. A félállásos tanári státus nem járható út, a bizonytalan hallgatói létszám miatt nem javasolt. Egyelöre a mentori munka egyszeri megbízással müködik, a lezárult munkafolyamat után kérdéses, hogy érkeznek-e, mikor érkeznek a következő hallgatók...

Az életpálya-modell elöirányozza a folyamat szükségességét, de a formai keretek csak hallgatói oldalról, az egyetemek felől rendezettek. A bérek rendezése iskolánk esetében kicsit megkésve, de viszonylag rendezetten alakult az előző évben. Minden érkező összeg kiosztásra került a mentor és a szakmai konzulensek közt az elvégzett munka arányában. Ez a tervezett ütem szerint idén is így alakul majd, ha intézményünk alszámlaszámot kap a KLIK-töl, amire az egyetemek utalhatnak.

Valódi nehézséget jelent továbbiakban, hogy ki kivel köti a szerződést. Mivel a többletmunkát a felsőoktatási intézmények finanszírozzák, intézmények közti a megállapodás, viszont a feladatot a mentortanárok látják el, így talán szerencsésebb megoldás lenne közvetlenül szerződéseket kötni a gyakoraltvezető mentortanárokkal.

E problémákra minden mentortanár keresi megoldást, várja a választ, hiszen a folyamat most már bizonyítottan eredményes, hozza a tervezett értékeket. Megfontolandó lenne még egyszer a finn mintára tekinteni, ahol a mentortanároknak a félállásnyi munkaideje a mentorálási munkáról, módszertani fejlesztésről szól. Egy mentorálttal dolgozik, akivel szakja egyezik, ezen kívül 4-6 fős csoportokkal, akiket szakmai konzulens vezet egy adott szakterületen. Egyéb teendőket a mentor követi nyomon. Barcy Magdolna finnekről írt tanulmányát áttekintve jó hír számunkra, hogy a pontokba szedett mentorálási folyamat minden tekintetben megvalósult intézményünkben (Barcy, 54. o.).

Természetesen a gyakorlatvezető mentortanár szakvizsgával záruló továbbképzés mélyebb betekintést nyújt a fenti folyamatba, és ajánlom is minden kollégámnak. Elöre láthatólag néhány év múlva csak végzett mentortanárok foglalkozhatnak majd a föiskola és egyetem hallgatóival mentorálási folyamat keretén belül, ezért is feltétlenül szükségesnek érzem a végzettség megszerzését. 


\section{Irodalom}

Barcy Magdolna: Segítő módszerek, fejlesztő-támogató eljárások/pdf./ 52. o. tatk.elte.hu/.../doc.../2237-segit-modszerek-fejleszt-tamogato-eljarasok

Benedek Mihály (2005): A „finn csoda” - és ami mögötte van. Új Pedagógiai Szemle, 4. sz. http://www.oki.hu/oldal.php?tipus=cikk\&kod=2005-04-vt-benedek-finn

Gyarmathy Éva (2012): Dislexia a digitális korszakban. Müszaki Kiadó, Budapest.

Kotschy Beáta (2003): Az iskolai oktatómunka tervezése. In.: Falus Iván (szerk.): Didaktika. Nemzeti Tankönyvkiadó, Budapest. 469-486. o.

Kotschy Beáta (2009): Új elemek a tanárképzés rendszerében. Educatio, 3. sz. 371-378.

Lenkovics Ildikó: A tanítás tanulása.

http://www.nyf.hu/pkk/sites/www.nyf.hu.pkk/files/tanarkepzo_anyagok/tanari_mester kepzes/osszef_szakm_gyak/02_a_tanitas_tanulasa.pdf

Mihály Ildikó (2003): Világraszóló oktatási sikerek és ami mögöttük van. A PISA-vizsgálat finn eredményeiről. Új Pedagógiai Szemle, 12. sz. 92-94.

Sándor József - Nagyné Fóris Katalin: Jó gyakorlatok a pályakezdő pedagógusok segítésére az INNOTE nemzetközi kutatásai alapján (EKTF)

http://jomite.nl/download/INNOTE_2011_10_18_Eger.pdf

Tari Annamária (2011): Z-generáció. Tericum Kiadó, Budapest. 